\title{
Sistem Pengendalian Persediaan Stok Bahan Baku Menggunakan Metode Economic Order Quantity di Pizzahut Setiabudi
}

\author{
Cindy Anindya Puspadev \\ Fakultas Teknologi Informasi, Universitas Stikubank, Jl. Tri Lomba Juang No.1, Semarang 50241, Indonesia
}

\section{INFORMASI ARTIKEL}

Sejarah Artikel:

Diterima Redaksi: 08 Juni 2021

Revisi Akhir: 12 Juni 2021

Diterbitkan Online: 14 Juni 2021

\section{KATA KUNCI}

Bahan Baku

Economic Order Quantity

Persediaan

KORESPONDENSI

E-mail: cindyanindya39@gmail.com

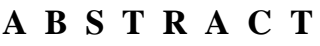

Pizzahut Setiabudi Semarang is a middle class restaurant in Indonesia that serves pizza, pasta and also various kinds of food. The process of recording stock inventories at Pizzahut Setiabudi currently still uses manual recording on books, both incoming and outgoing materials. In addition, the procurement process for raw material stock only uses estimates, this can lead to excess stock in the warehouse or actually experience a stock shortage which can later hamper the operational process of the business. In this research, we build a raw material inventory control system to help restaurants manage material stock data using the Economic Order Quantity (EOQ) method. EOQ is a method used to optimize the purchase of raw materials that can reduce inventory costs so that the efficiency of material inventory in the company can run well.
\end{abstract}

\section{PENDAHULUAN}

Saat ini usaha kuliner sudah semakin menjamur di kalangan pengusaha sehingga menyebabkan persaingan semakin ketat. Selain masalah strategi pasar untuk mengatasi persaingan di usaha kuliner, pengelola atau pemilik juga perlu memperhatikan pengendalian persediaan stok bahan karena sangat menentukan kelancaran kegiatan usaha.[1] Pengendalian persediaan bahan baku untuk usaha kuliner sangat penting untuk mengatasi atau mencegah pembelian bahan baku yang berlebihan sehingga mengalami kerusakan dan tidak dapat terpakai lagi dan dapat menimbulkan kerugian dalam usaha.[2] Pizza Hut merupakan usaha dibidang kuliner yang memiliki ratusan cabang yang tersebar di Indonesia, salah satunya yaitu Pizzahut setiabudi yang berlokasi di kota Semarang. Selama ini restoran melakukan pemesanan bahan baku bila stok bahan mulai menipis dan juga pemesanan hanya berdasarkan perkiraan saja sehingga terkadang restoran mengalami kelebihan stok bahan yang menyebabkan menumpuknya bahan di gudang ataupun kekurangan stok. Dengan sistem pengadaan bahan baku seperti ini tentunya sangat tidak efisien dan kurang menguntungkan karena memakan biaya.
Proses pencatatan persediaan stok bahan baku di Pizzahut Setiabudi Semarang juga masih menggunakan cara manual. Proses ini masih sering menghambat kegiatan usaha karena membutuhkan waktu yang lama untuk mendapatkan informasi persediaan bahan, sehingga akan berdampak pada keterlambatan dalam pemesanan bahan untuk pemesanan berikutnya, serta adanya resiko kehilangan atau kerusakan pada data persediaan stok. Berdasarkan uraian permasalahan diatas, maka diperlukan sebuah sistem untuk menunjang proses pengendalian persediaan bahan baku agar kegiatan oprasional usaha dapat berjalan dengan lancar tanpa kendala dan biaya yang dikeluarkan dapat ditekan seminimal mungkin. Oleh karena itu, penelitian ini membuat sebuah sistem pengendalian persediaan stok bahan baku yang dilengkapi dengan metode Economic Order Quantity (EOQ). Sistem ini membantu mengolah data store secara terkomputerisasi yang dapat mengelola data bahan masuk, bahan keluar, proses update stok bahan dan laporan terkait persediaan bahan. Metode EOQ nantinya dapat membantu menentukan jumlah pemesanan bahan baku yang optimal dengan biaya yang dikeluarkan seminimal mungkin sehingga perusahaan dapat mencapai keuntungan yang maksimal.[3] Sistem ini juga dilengkapi dengan perhitungan ROP (Reorder Point) yang dapat menentukan titik pemesanan kembali untuk mengatasi 
kekurangan stok bahan baku jika stok bahan baku yang dipesan terlambat datang[4].

\section{TINJAUAN PUSTAKA}

Pada penelitian Nursafi'at membahas mengenai penerapan metode Eonomic Order Quantity (EOQ) pada aplikasi inventory air mineral, metode EOQ digunakan untuk memprediksi bahan baku yang akan dipesan. Pada penelitian yang dilakukan Surya Fitri menyatakan metode EOQ dapat menentukan jumlah stok order yang optimal.

Penelitian Teungku Nurainun menyatakan metode EOQ dapat menentukan jumlah dan frekuensi pemesanan kembali. Penelitian selanjutnya dilakukan oleh Isnaini Muhandhis dan Angga Pradana menyatakan metode EOQ dapat menentukan jumlah pemesanan barang dan waktu untuk pemesanan kembali.

\section{METODOLOGI}

Adapun metode penelitian yang digunakan dalam penyusunan jurnal ini adalah :

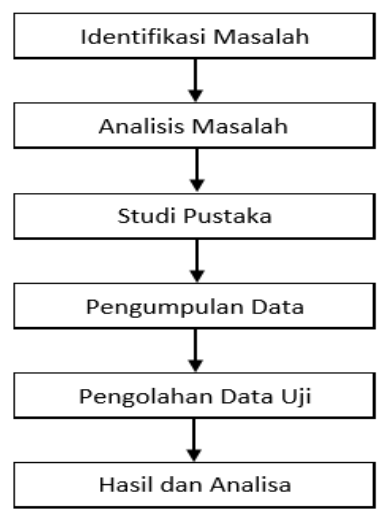

Gambar 1. Kerja Penelitian

Berikut merupakan urutan-urutan langkah kerja berdasarkan gambar 1 ialah sebagai berikut :

1. Identifikasi Masalah

Identifikasi masalah dalam penelitian ini adalah proses serta hasil pengenalan permasalahan yang terjadi di Pizzahut Setiabudi Semarang dalam melakukan pengelolaan persediaan stok bahan baku.

2. Analisis Masalah

Setelah mengidentifikasi masalah langkah selanjutnya yaitu menganalisis masalah, analisis masalah bertujuan untuk memperoleh pemahaman lebih mendetail mengenai masalah yang terjadi

3. Studi Pustaka

Studi pustaka dilakukan dengan tujuan untuk mengetahui metode apa yang akan digunakan untuk menyelesaikan permasalahan yang akan diteliti, serta mendapatkan dasardasar referensi yang kuat bagi peneliti dalam menerapkan suatu metode yang digunakanya. Studi pustaka dilakukan dengan pencarian landasan teori melalu sumber yang terkait seperti artikel, buku, jurnal, PHP dan MySQL dan literaturliteratur tentang masalah sitem pengendalian persediaan stok bahan baku menggunakan metode Economic Order Quantity.

4. Pengumpulan Data

44 Cindy Anindya Puspadev
Pengumpulan data dilakukan dengan melakukan observasi yaitu melakukan pengamatan secara langsung dan pegumpulan informasi melalui wawancara serta pencatatan informasi mengenai data yang diperlukan pada Pizzahut Setiabudi.

5. Pengolahan Data Uji,

Pada tahap ini hasil dari analisis diperiksa kembali dan diuji lagi menggunakan bahasa pemrograman PHP dan database MySQL dengan pengentrian data secara manual.

6. Hasil dan Analisa

Setelah melakukan pengujian dengan bahasa pemrograman PHP dan database MySQL maka didapat hasil analisis. Hasil analisa yang telah didapatkan dapat dijadikan sebagai bahan pertimbangan restoran apakah akan melakukan peningkatan dalam pengendalian persediaan stok bahan.

\section{HASIL DAN PEMBAHASAN}

\subsection{Economic Order Quantity}

Economic Order Quantity (EOQ) digunakan untuk menentukan kuantitas pesanan persediaan yang meminimumkan biaya langsung penyimpanan persediaan dan biaya kebalikannya (inverse cost)[2] pemesanan persediaan. Rumus EOQ yang biasa digunakan adalah [5]:

$$
E O Q=\sqrt{\frac{2 \times D x S}{H}}
$$

Keterangan :

$\begin{array}{lll}\mathrm{D} & = & \text { Jumlah pemakaian bahan } / \text { tahun } \\ \mathrm{S} & = & \text { Biaya per pesanan } \\ \mathrm{H} & = & \text { Biaya penyimpanan } / \text { tahun }\end{array}$

Persediaan pengaman (safety stock) adalah persediaan tambahan yang diadakan untuk melindungi atau menjaga kemungkinan terjadinya kekurangan bahan (stock out)[4]. Safety stock dihitung menggunakan metode perbedaan pemakaian maksimum dan pemakaian rata-rata sebagai berikut[2] :

$S S \quad=\quad(\operatorname{MaxP}-\operatorname{RataP}) x \mathrm{~L}$

Keterangan :

$\begin{array}{lll}S S & = & \text { Safety Stock } \\ \mathrm{MaxP}= & \text { Pemakaian maksimal dalam periode tertentu } \\ \text { RataP }= & \text { Rata-rata pemakaian dalam periode tertentu }\end{array}$

$\begin{array}{lll}\text { RataP } & = & \text { Rata-rata pemakaian dalam periode tert } \\ \mathrm{L} & = & \text { Lead time (Waktu tunggu pemesanan) }\end{array}$

\subsection{Reorder Point}

Setelah mendapatkan hasil perhitungan safety stock maka selanjutnya menentukan kapan pesanan kembali dilkakukan atau Reorder Point (ROP)[1]. Untuk menghitung berapa Reorder Point (ROP) adalah[6] :

$\mathrm{ROP}=\quad$ Safety Stock $+(L x d)$

Keterangan :

ROP $=$ Titik pemesanan kembali

$L=\quad$ Lead time (Waktu tunggu)

SS = Safety stock (Stok pengaman) 
Penentuan persediaan maksimum yang dapat disimpan di gudang juga perlu dipertimbangkan mengingat kapasitas gudang yang terbatas[2]. Perhitungan persediaan maksimum dapat menggunakan rumus berikut[2] :

$$
M 1=E O Q+S S
$$

Keterangan :

$M 1=$

$E O Q=$

Maximum inventory (Persediaan maksimum)

SS $=$

\subsection{Implementasi Perangkat Lunak}

Pengembangan sistem diimplementasikan menggunakan bahasa pemrograman PHP versi 7.3.27 dan pengolahan data menggunakan database Mysql versi 5.1 dengan XAMPP

\section{Halaman Login}

Pada saat sistem dijalankan maka yang muncul pertama kali adalah form login. Untuk masuk ke sistem user harus mengisi username dan password. Jika login berhasil maka user akan dialihkan ke meu stok bahan baku. Berikut tampilan form login sistem :

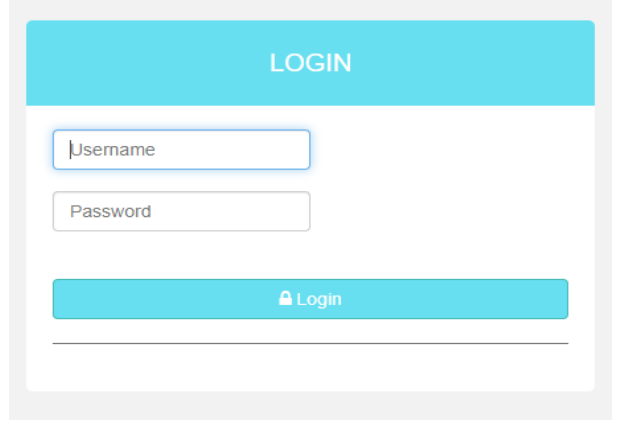

Gambar 2. Halaman Login

2. Halaman Stok Bahan Baku

Pada halaman stok bahan baku user dapat melihat daftar stok bahan baku, mengelola data stok bahan baku seperti menambah data stok, mengubah data stok, menghapus data stok dan juga dapat mencetak laporan stok bahan. Berikut tampilan halaman stok bahan baku pada sistem :

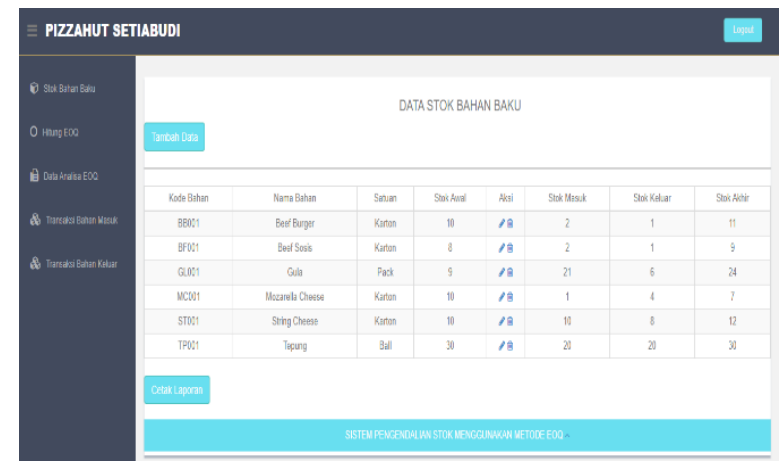

Gambar 3. Halaman Stok Bahan Baku
Halaman hitung EOQ digunakan untuk menghitung menggunakan metode EOQ untuk pengendalian persediaan stok bahan baku di Pizzahut Setiabudi Semarang.

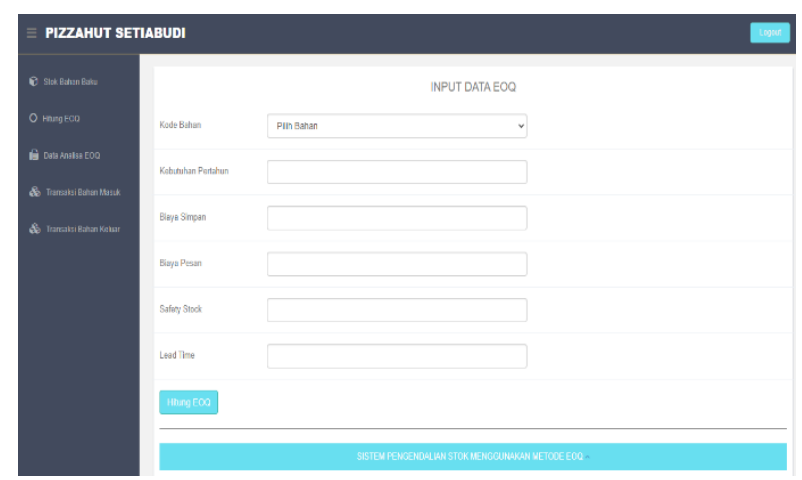

Gambar 4. Halaman Hitung EOQ

4. Halaman Data Analisa EOQ

Pada halaman ini akan ditampilkan daftar hasil perhitungan menggunakan metode EOQ. User dapat menambah data EOQ baru, menghapus hasil laporan perhitungan maupun mencetak laporan hasil perhitungan. Berikut tampilan halaman data analisa EOQ :

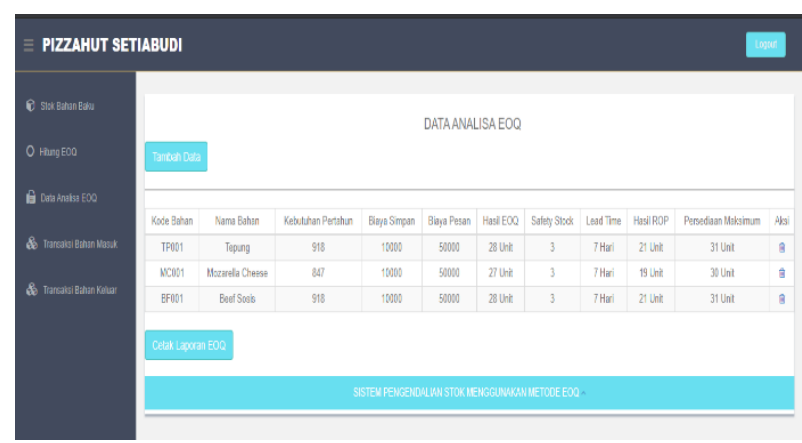

Gambar 5. Halaman Data Analisa EOQ

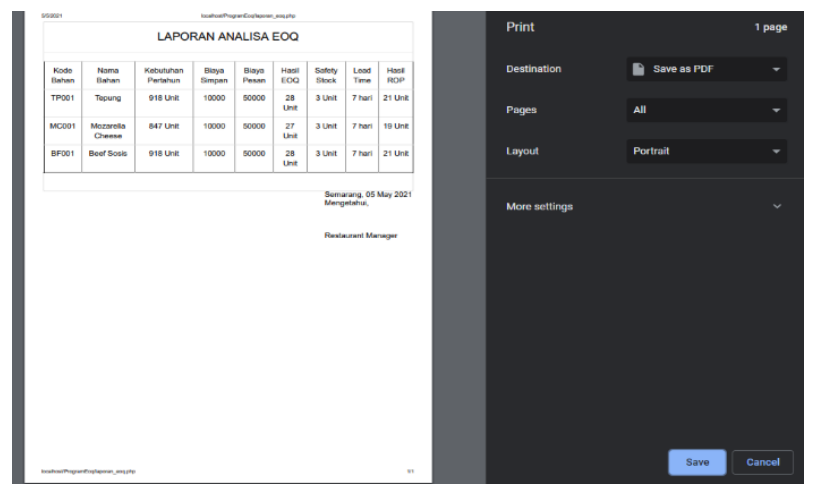

Gambar 6. Hasil Laporan Analisa EOQ

5. Halaman Transaksi Bahan Masuk

Halaman transaksi bahan masuk menampilkan daftar transaksi bahan masuk. Pada halaman ini user dapat mengelola data stok bahan masuk seperti menambah transaksi bahan masuk dan menghapus data stok bahan masuk. Berikut tampilan halaman stok bahan masuk pada sistem : 


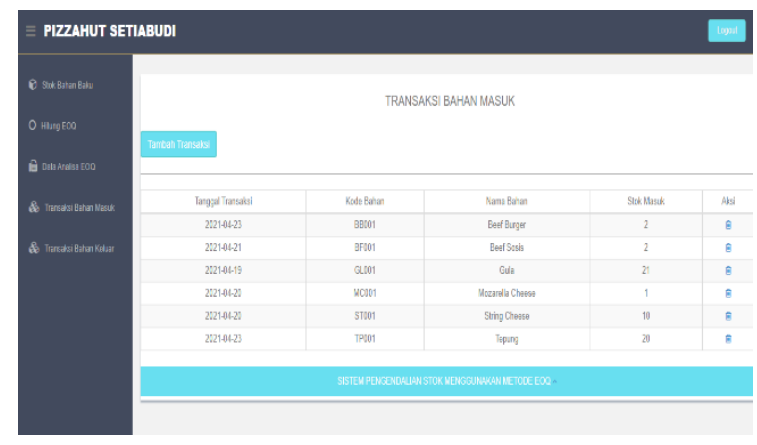

Gambar 7. Halaman Stok Bahan Masuk

6. Halaman Transaksi Bahan Keluar

Halaman transaksi bahan keluar menampilkan daftar transaksi bahan keluar. Pada halaman ini user dapat mengelola data stok bahan keluar seperti menambah transaksi bahan keluar dan menghapus data stok bahan keluar. Berikut tampilan halaman stok bahan keluar pada sistem :

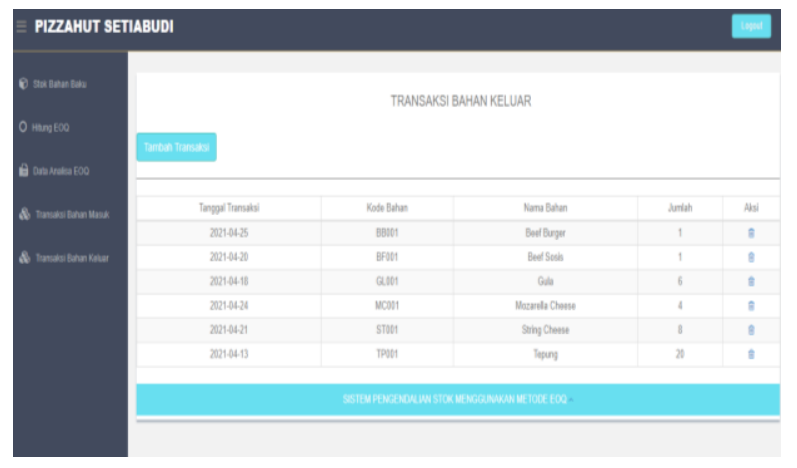

Gambar 8. Halaman Stok Bahan Keluar

\subsection{Pengujian Sistem}

Sistem pengendalian persediaan stok bahan baku di gudang menggunakan metode EOQ dengan mempertimbangkan Reorder Point dan Safety Stock sehingga dapat diketahui titik pemesanan kembali dan jumlah barang yang dipesan dengan optimal[7]. Berikut contoh data pengadaan bahan baku :

Tabel 1. Data Stok Tepung Tahun 2019 dan 2020

\begin{tabular}{|c|c|c|c|c|}
\hline Bulan & 2019 & 2020 & $\begin{array}{c}\text { Biaya } \\
\text { Pemesanan }\end{array}$ & $\begin{array}{c}\text { Biaya } \\
\text { Penyimpanan }\end{array}$ \\
\hline Januari & 65 Ball & 58 Ball & Rp. 50.000 & Rp. 10.000 \\
\hline Febuari & 67 Ball & 60 Ball & Rp. 50.000 & Rp. 10.000 \\
\hline Maret & 69 Ball & 62 Ball & Rp. 50.000 & Rp. 10.000 \\
\hline April & 71 Ball & 65 Ball & Rp. 50.000 & Rp. 10.000 \\
\hline Mei & 73 Ball & 67 Ball & Rp. 50.000 & Rp. 10.000 \\
\hline Juni & 75 Ball & 70 Ball & Rp. 50.000 & Rp. 10.000 \\
\hline Juli & 78 Ball & 72 Ball & Rp. 50.000 & Rp. 10.000 \\
\hline Agustus & 80 Ball & 74 Ball & Rp. 50.000 & Rp. 10.000 \\
\hline September & 82 Ball & 76 Ball & Rp. 50.000 & Rp. 10.000 \\
\hline Oktober & 83 Ball & 78 Ball & Rp. 50.000 & Rp. 10.000 \\
\hline November & 85 Ball & 80 Ball & Rp. 50.000 & Rp. 10.000 \\
\hline Desember & 90 Ball & 85 Ball & Rp. 50.000 & Rp. 10.000 \\
\hline Jumlah & $\begin{array}{l}918 \\
\text { Ball }\end{array}$ & 847 Ball & & \\
\hline $\begin{array}{l}\text { Rata - } \\
\text { Rata }\end{array}$ & $\begin{array}{l}76,5 \\
\text { Ball }\end{array}$ & $\begin{array}{l}70,6 \\
\text { Ball }\end{array}$ & & \\
\hline
\end{tabular}

Keterangan :

$$
\begin{aligned}
& \mathrm{D}=847 \text { Ball } \\
& \mathrm{S}=\text { Rp. } 50.000 \\
& \mathrm{H}=\text { Rp. } 10.000 \\
& \mathrm{~L}=7 \text { Hari } / 0,23333 \text { Bulan }
\end{aligned}
$$

Berikut ini merupakan salah satu contoh perhitungan manual data stok bahan baku menggunakan EOQ yang hasilnya akan dibandingkan dengan hasil yang ditampilkan oleh aplikasi. Perhitungan yang ada dalam aplikasi dianggap valid jika sesuai dengan perhitungan manual.

1. Jumlah pemesanan optimum

$$
E O Q=\sqrt{\frac{2 \times 847 \times 50.000}{120.000}}=27
$$

2. Persediaan Pengaman

$$
\text { SS } \quad=(85-70,6) \times 0,23333=3,36=3
$$

3. Titik Pemesanan Kembali (Reorder Point)

$$
\text { ROP }=(70,6 \times 0,23333)+3=19
$$

4. Persediaan Maksimum

$$
M 1 \quad=27+3=31
$$

Berikut hasil perhitungan pada sistem

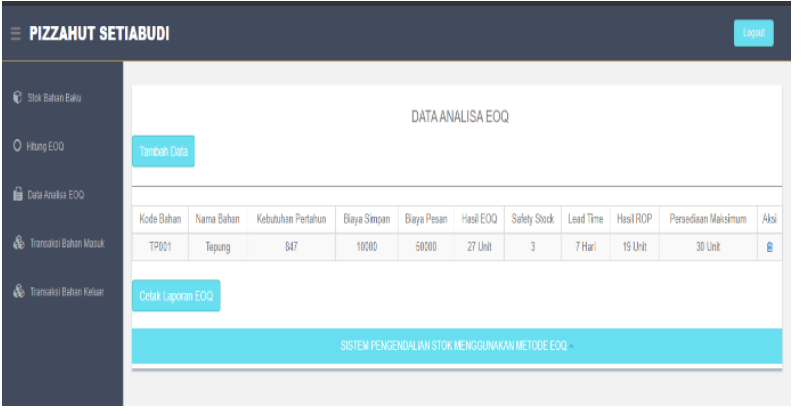

Gambar 10. Hasil Perhitungan di Sistem Pengendalian Persediaan

Hasil perhitungan sistem sudah sesuai dengan perhitungan manual, sehingga perhitungan sistem bisa dikatakan valid. Pemakaian rata-rata bahan baku tepung adalah 70,6 ball. Hasil Perhitungan EOQ sebesar 27 yang artinya jumlah pemesanan optimum untuk setiap kali pemesanan adalah 27 ball. Persediaan pengaman sebesar 3 ball dan titik pemesanan kembali adalah ketika stok tepung mencapai 19 ball. Persediaan maksimum yang boleh disimpan di gudang adalah sebesar 31 ball.

\section{KESIMPULAN DAN SARAN}

Sistem pengendalian persediaan stok bahan baku ini membantu mengolah data store secara terkomputerisasi sehingga dapat mempermudah dalam mengelola data stok bahan, transaksi bahan masuk, transaksi bahan keluar dan juga dilengkapi metode Economic Order Quantity yang dapat menentukan jumlah stok pemesanan kembali yang optimal dan titik pemesanan kembali (Reorder Point). 


\section{DAFTAR PUSTAKA}

[1] P. S. Informatika and A. Subronto, "Naskah Publikasi IMPLEMENTASI METODE ECONOMIC ORDER QUANTITY UNTUK PENGENDALIAN PERSEDIAAN BARANG SECARA OPTIMAL," 2020.

[2] E. Astriyani, D. Apriani, and M. M. Sari, "Sistem Informasi Pengendalian Persediaan Barang Menggunakan Metode Economic Order Quantity (EOQ)," IJAcc, vol. 1, no. 2, pp. 132-139, 2020, doi: 10.33050/jakbi.v1i2.1414.

[3] R. Rahmawati, A. A. G. Agung, and F. Sukmawati, "Aplikasi Perhitungan Persediaan Bahan Baku dengan Metode Economic Order Quantity Berdasarkan Varian Produk," J. Nas. Pendidik. Tek. Inform., vol. 5, no. 1, p. 34, 2016, doi: 10.23887/janapati.v5i1.9915.

[4] T. Nurainun, "Perancangan Sistem Informasi Pengendalian Persediaan Bahan Pokok (Studi Kasus Swalayan Buyung Family Pekanbaru)," J. Tek. Ind. J. Has. Penelit. dan Karya Ilm. dalam Bid. Tek. Ind., vol. 4, no. 2, p. 139, 2020, doi: 10.24014/jti.v4i2.6761.

[5] W. V. Andini and A. Slamet, "Analisis Optimasi Persediaan Bahan Baku Dengan Menggunakan Metode Economic Order Quantity Pada Cv. Tenun/Atbm Rimatex Kabupaten Pemalang," Manag. Anal. J., vol. 5, no. 2, pp. 143-148, 2016, [Online]. Available: https://journal.unnes.ac.id/sju/index.php/maj/article/vie w/7901.

[6] S. F. Handayani, "Implementasi Metode Economic Order Quantity(Eoq) Pada Persediaan Bahan Baku Sabun Ud. Lautan Kimia Medan,” J. Pelita Inform., vol. 18, no. April, pp. 240-245, 2019.

[7] Suenawati, "Penerapan Metode Economic Order Quantity Pada Sistem Informasi Manajemen Persediaan Barang Di Pt.Intan Triputra Abadi," no. September, pp. 8-45, 2019, [Online]. Available: http://elibrary.unikom.ac.id/id/eprint/1140.

\section{BIODATA PENULIS}

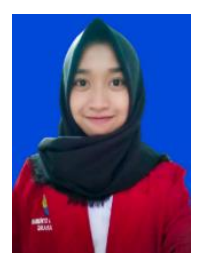

Cindy Anindya Puspadev

Mahasiswa Universitas Stikubank Semarang

Program Studi Teknik Informatika

Email : cindyanindya39@gmail.com 